Nigerian Journal of Environmental Sciences and Technology (NIJEST)

www.nijest.com

ISSN (Print): 2616-051X ｜ＩSSN (electronic): 2616-0501

Vol 2, No. 1 March 2018, pp 46 - 55

\title{
Performance Assessment of Biological Wastewater Treatment at WUPA Wastewater Treatment Plant, Abuja, Nigeria
}

\author{
Chukwu M.N. ${ }^{1, *}$ and Oranu C.N. ${ }^{1}$ \\ ${ }^{1}$ Biology Unit, Department of Pure and Applied Sciences, Faculty of Science, National Open University of \\ Nigeria, Abuja, Nigeria \\ Corresponding Author: *mchukwu@ noun.edu.ng
}

\begin{abstract}
Biological treatment of wastewater from Wupa Wastewater Treatment Plant, Abuja was investigated. Wastewater samples were collected from the inlet and effluent point (before and after the ultra violet radiation unit) of the treatment plant. The physicochemical parameters; temperature, $\mathrm{pH}$, conductivity, total dissolved solids (TDS), total suspended solids (TSS) and dissolved oxygen (DO) were measured. The Biological Oxygen Demand (BOD) and Chemical Oxygen Demand (COD) were obtained from samples collected from the influent and effluent points using Standard methods specified by the American Public Health Association (APHA). The water samples were also analysed for the presence of bacterial organisms via Total Coliform Count (TCC), Total Bacteriological Count (TBC) and Faecal Count (FC). At the end of the analysis, the percentage removal efficiency of the ultra violet radiation for TCC, TBC and FC were calculated. Results showed that the mean removal efficiency for TCC, TBC and FC were $99.6 \%, 89.9 \%$ and $98.9 \%$ respectively; all within the permissible limit of World Health Organization and Federal Ministry of Environment. There was a reduction of $81.5 \%$ in COD, $98.9 \%$ in BOD which met the required effluent standards. There was significant differences between the $\mathrm{pH}$, TSS, DO, COD and BOD of the influent and effluent $(\mathrm{P}<0.05)$. These results showed that there is an urgent need for appropriate steps to be taken for proper management and sanitation of the wastewater before discharging it to the stream, to ensure total conformity with the approved standards.
\end{abstract}

Keywords: Influent, Effluent, Biological Oxygen Demand, Physicochemical, Conductivity, Bacteriological count

\subsection{Introduction}

Wastewater is any water that has been adversely affected in quality by anthropogenic influence. It comprises liquid waste discharged by domestic residences, commercial properties, and industrial and or agricultural wastes, and can encompass a wide range of potential contaminants and concentrations (Nielsen et al., 2004). Waste water that contains urine, faeces, kitchen and laundry waste is referred to as sewage.

At the beginning of the $20^{\text {th }}$ Century, septic tank was introduced as a means of treating domestic sewage from individual households both in suburban and rural areas. Then a few cities and industries recognised that the discharge of sewage directly into streams caused health problems and this led to the development of sewage treatment facilities referred to as waste water treatment plants (Ikupolati, 2005). Wastewater Treatment Plants (WWTPs) are complex systems which include a large number of biological, physicochemical, and biochemical processes (Sotomayor et al., 2001).

The activated sludge process is the most widely applied biological treatment of liquid waste, treating both municipal sewage and a variety of industrial wastewaters (Aguilar-López et al., 2013; Slater, 2006). The microbiological quality of effluent consumable water is a concern to consumers (Wupa dwellers), water suppliers (Wupa Wastewater Treatment Plant), and regulatory and public health authorities alike. Most recent gastrointestinal outbreaks that have been reported throughout the world demonstrated that transmission of pathogens by effluent consumable water remains a significant cause 
of illness (Hunter and Syed, 2001). This study was designed to examine the Performance Assessment of biological waste water treatment which is considered as one of the most efficient methods of waste water treatment.

\subsection{Materials and Methods}

\subsection{Study area}

This research work was carried out in the Quality Control Laboratory of Wupa Waste Water Treatment Plant Abuja, Nigeria. Wupa Wastewater Treatment Plant is located at Cadastral Zone COO Institute \& Research District of Abuja FCT, Latitude and Longitude. It is close to Wupa River and it covers an area of 297,900 square meters. WWTP which is one of the largest in the world was constructed to treat sewage generated from phase 1, II, III of Abuja Metropolis. It was designed to handle the waste generated by 700,000 Population Equivalent (PE) and expandable to 1,000,000 PE, thus the Plant can accommodate an average dry weather inflow of 5,500 cubic meter per hour and a wet weather inflow of 9,000 cubic meter per hour. The plant operates on the activated sludge process that relies on microbial population in mixed suspension to achieve the waste water treatment. The plant was constructed to address the growing concern of the disposal of human waste, as Abuja metamorphosed into a global city (Saminu et al., 2017).

\subsection{Sampling points}

Four (4) sampling points from Wupa Wastewater Treatment Plant were selected for the study: A; Inlet-the first channel that receives raw wastewater from different homes, B; Raw sewage (influent)just as it was discharged into the sewage treatment plant, C; Effluent (before ultra violet rays)-just before it passes through the most important stage of the waste water treatment; the UV and D; Effluent (after ultra violet rays)-just as it passes through the ultra violet ray channel, before it is discharged into the Wupa River.

\subsection{Sample collection}

Grab method of sampling was used at the different sampling points. Sixteen samples were collected from each of the four sampling points. Each $250 \mathrm{ml}$ sterile sample bottle was dipped into the wastewater at a depth of $30 \mathrm{~cm}$, and placed in the direction of the flow of water. The cork was removed and the sample was taken, leaving space for agitation. The samples were properly labelled, then stored in a cooler and transferred to the laboratory for analysis (Benethan, 2003).

\subsection{Determination of physicochemical parameters of the water samples}

The physicochemical parameters; conductivity, temperature, Hydrogen ion concentration $(\mathrm{pH})$, Dissolved Oxygen (DO), Total Dissolved Solids (TDS) and Total Suspended Solid (TSS) were determined using Electrometric method (APHA, 2005).

\subsection{Determination of the Chemical Oxygen Demand (BOD) level of the water samples}

The Chemical Oxygen Demand level was determined using the closed reflux method by Merck KGaA kit, 64271 Darmstadt, Germany, according to the manufacturer's instruction.

\subsection{Determination of the Biological Oxygen Demand (BOD) level of the water samples}

The Biological Oxygen Demand Level was determined using the Respirometric method; the standard method recognized by U.S. EPA and a labelled Method 5210B in the Standard Methods for Examining water and waste water (Lenore et al., 2005).

\subsection{Bacteriological analysis (count) of the waste water samples}

Ninety-two (92) McCartney bottles were used; two of which were used as control for dev-lactose and EC Broth media. Dev-lactose media was used to determine Total Coliform Count (TCC) by Fermentation tube technique. Same method was also used in the determination of Fecal Count (FC) using EC broth media (Uzoigwe and Agwa, 2012). Serial dilutions of the samples were done using pour plate method according to Willey et al. (2008). 


\subsection{Presumptive and confirmatory test}

Presumptive and confirmatory test for detection of the presence of coliforms was carried out as described by Chessbrough (2004).

\subsection{Statistical Analysis}

The data were analysed using two way analysis of variance. Further analysis was carried out using Pearson Correlation Coefficient at $5 \%$ level of significance $(\mathrm{P}<0.05)$.

\subsection{Results and Discussion}

\subsection{Physicochemical parameters of the water samples}

\subsubsection{Temperature}

There was a slight variation in temperature between the influent and effluent (Figure 1). The influent's temperature decreased as that of the effluent increased for the first three weeks followed by same values for both weeks 4 and $5\left(25.3^{\circ} \mathrm{C}\right.$ and $27.1^{\circ} \mathrm{C}$ respectively). Thereafter, the temperature of the influent increased as that of the effluent decreased for the remaining period of the work. There was no significant difference between the temperatures of the influent and the effluent $(P>0.05)$. The similarity in the temperatures of both the influent and effluent was probably because the weather condition was stable during the study period. This is in agreement with the requirement for temperature in accordance to National Guidelines of the Federal Ministry of Environment (2013) that temperature should not be greater than $40^{\circ} \mathrm{C}$ (Table 1).

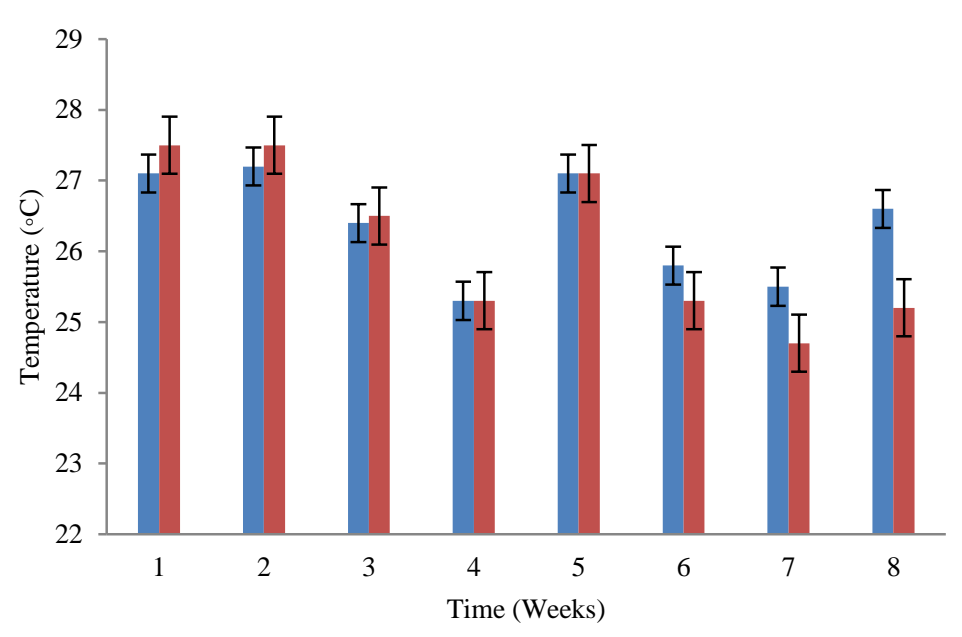

Influent

Effluent

Figure 1: Variations in temperatures $\left({ }^{\circ} \mathrm{C}\right)$ of Influent and Effluent (values shown are Mean $\pm \mathrm{SE}$ )

Table 1: Effluent limits for various parameters

\begin{tabular}{|c|l|c|c|c|}
\hline S/N & \multicolumn{1}{|c|}{ Parameters } & $\begin{array}{l}\text { Results for effluent } \\
\text { (expressed in mean })\end{array}$ & $\begin{array}{l}\text { W.H.O's limit for } \\
\text { effluent }\end{array}$ & $\begin{array}{l}\text { F.M.Env limit for } \\
\text { effluent }\end{array}$ \\
\hline 1 & Temperature $\left({ }^{\circ} \mathrm{C}\right)$ & 26.1 & $<40$ & $<40$ \\
\hline 2 & $\mathrm{pH}$ & 6.95 & $6.5-8.5$ & $6-9$ \\
\hline 3 & Conductivity $(\mu \mathrm{S} / \mathrm{cm})$ & 267 & 1250 & ----- \\
\hline 4 & Total Suspended Solids(mg/l) & 79.13 & ----- & 30 \\
\hline 5 & Total Dissolved Solids(mg/l) & 167 & 1000 & 2000 \\
\hline 6 & Dissolved Oxygen(mg/l) & 5.55 & $7-10$ & ----- \\
\hline 7 & Biological Oxygen Demand(mg/l) & 2.75 & 30 & 50 \\
\hline 8 & Chemical Oxygen Demand(mg/l) & 24 & 100 & 80 \\
\hline 9 & $\begin{array}{l}\text { Total Coliform Count (daily average, } \\
\text { MPN/ml) }\end{array}$ & 6.5 & $400 \mathrm{MPN} / 100 \mathrm{ml}$ & $400 \mathrm{MPN} / 100 \mathrm{ml}$ \\
\hline 10 & Fecal Count(daily average, MPN/ml) & 6.13 & $0 / 100 \mathrm{ml}$ & $0 / 100 \mathrm{ml}$ \\
\hline 11 & $\begin{array}{l}\text { Total Bacteria Count(daily average, } \\
\text { MPN/ml) }\end{array}$ & 29.4 & $400 \mathrm{MPN} / 100 \mathrm{ml}$ & $400 \mathrm{MPN} / 100 \mathrm{ml}$ \\
\hline
\end{tabular}

Source: Federal Ministry of Environment (FMEnv) (2013), World Health Organization (WHO) (2003) 


\subsubsection{Hydrogen ion concentration $(\mathrm{pH})$}

Figure 2 indicated that $\mathrm{pH}$ values of influent ranged from 7.162 - 7.466 and those of effluent from $6.728-7.239$ with a mean of 6.95; the permissible limit of $\mathrm{pH}$ by Federal Ministry of Environment (FMEnv, 2013) and World Health Organization (Table 1). There was an inversely proportionality between the $\mathrm{pH}$ values of the influent and effluent and significant difference between them $(\mathrm{P}<0.05)$ throughout the study period.

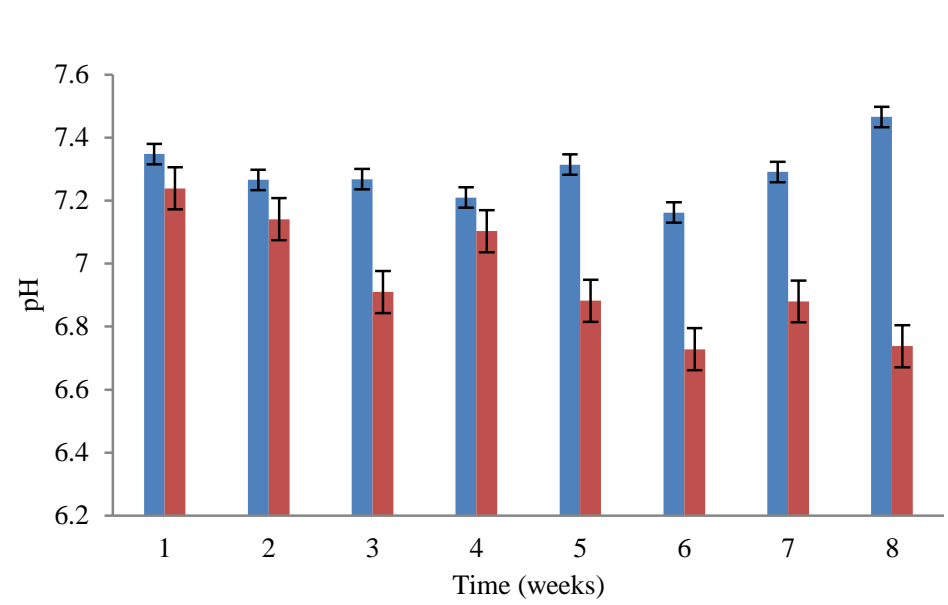

Influent

- Effluent

Figure 2: Variations in $\mathrm{pH}$ of Influent and Effluent (values shown are Mean $\pm \mathrm{SE}$ )

\subsubsection{Conductivity}

Figure 3 indicated that there was a slight variation between the conductivities of influent and effluent. The conductivities of influent decreased as those of the effluent increased as the experiment progressed except in week 3 where the reverse was the case. There was no significant difference between the conductivities of the influent and those of the effluent $(\mathrm{P}>0.05)$. The conductivity of the influent is usually higher than that of effluent, under normal conditions, but this was not so during the period of study because of the sampling time, $\mathrm{pH}$ and temperature changes. High $\mathrm{pH}$ increased the ionic concentration of effluent, thus the conductivity of effluent was increased. The mean conductivity of effluent, $267 \mu \mathrm{S} / \mathrm{cm}$ is in agreement with World Health Organization (WHO) limit for conductivity $(1250 \mu \mathrm{S} / \mathrm{cm})($ Table 1$)$.

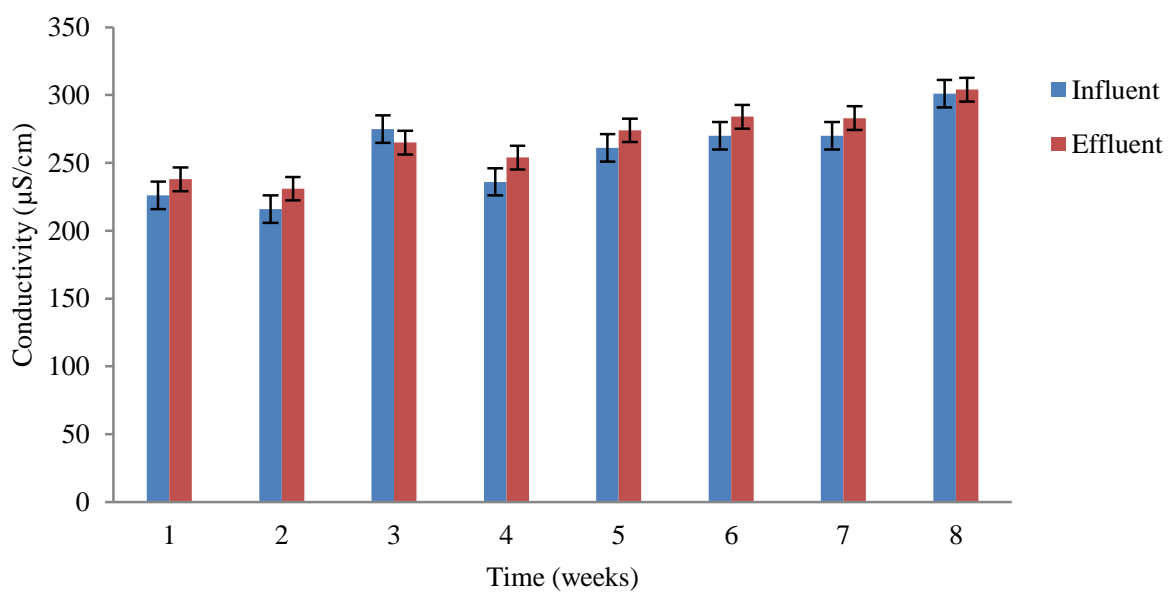

Figure 3: Variations in conductivity $(\mu \mathrm{S} / \mathrm{cm})$ of Influent and Effluent (values shown are Mean $\pm \mathrm{SE}$ )

\subsubsection{Total Dissolved Solid (TDS)}

Figure 4 showed that there was an inverse proportionality between the values of the TDS of influent and those of the effluent throughout the study period. There was no significant difference between the TDS of the influent and effluent ( $P>0.05)$. The TDS values of the effluent $(70-292 \mathrm{mg} / \mathrm{l})$ agreed with the requirement for TDS values according to the National Guidelines of the Federal Ministry of 
Environment (2013) which states that TDS value of effluent should not be greater than $2000 \mathrm{mg} / \mathrm{l}$ (Table 1). The overall removal efficiency ultra violet unit for TDS was 15.6\%-76.5\% while the mean removal efficiency was $36 \%$. This showed that the effluent was fairly safe to be discharged.

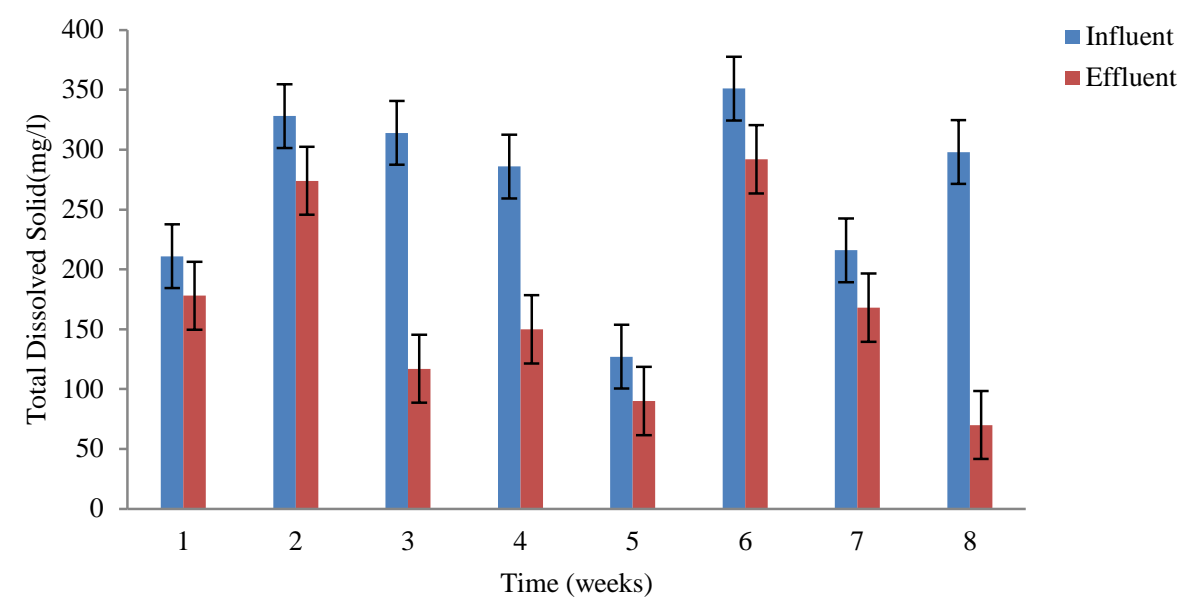

Figure 4: Variations in Total Dissolved Solid (mg/l) of Influent and Effluent (values shown are Mean $\pm \mathrm{SE})$

\subsubsection{Total Suspended Solids (TSS)}

There was a large variation between the TSS of influent and effluent (Figure 5). The TSS of influent was indirectly proportional to that of the effluent with a significant difference between them (P < 0.05 ) throughout the study period. The overall removal efficiency of pollutant in the treatment plant was $31.3-98.5 \%$ with a mean removal efficiency of $81.5 \%$. This is in agreement with the findings of Healy et al. (2006) who observed TSS removal efficiency of $99 \%$.

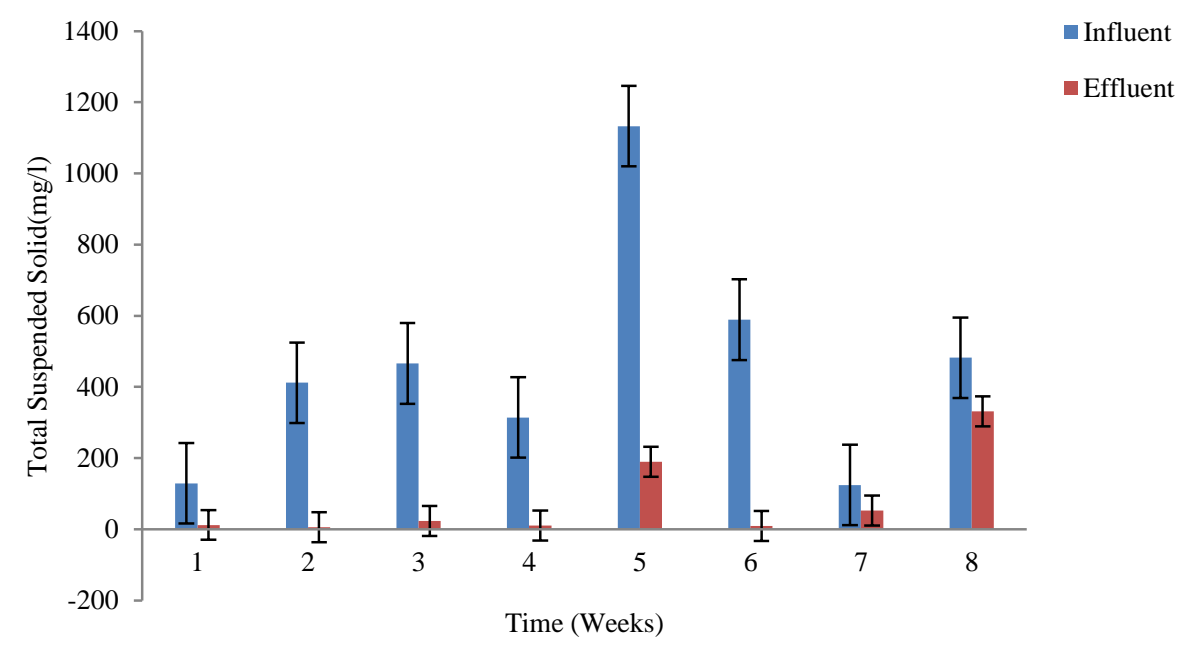

Figure 5: Variations in Total Suspended Solids (mg/l) of Influent and Effluent (values shown are Mean \pm SE)

\subsubsection{Dissolved Oxygen (DO)}

The DO of the influent was inversely proportional to that of the effluent throughout the study period (Figure 6). The DO concentration of the effluent was obviously higher than that of influent probably because the effluent contained a small quantity of organic matter hence a small quantity of DO was used by microorganisms to break them down. There was thus a large quantity of unused DO in the effluent. There was a significant difference between the DO of influent and that of the effluent $(\mathrm{P}<$ $0.05)$. 


\subsection{Chemical Oxygen Demand (COD)}

Figure 7 indicated that the COD of influent was inversely proportional to that of the effluent throughout the study period. There was a significant difference between the COD of influent and the effluent $(\mathrm{P}<0.05)$. This was probably because the effluent contained small quantities of organic and inorganic loads, thus lower concentration of dissolved oxygen was needed for decomposition of the organic matter. The effluent COD range of 7-96mg/l is within the World Health Organization limit for effluent which is $100 \mathrm{mg} / \mathrm{l}$ (Table 1). The overall removal efficiency of the Ultra Violet unit for COD is $72.2-98.6 \%$ and mean removal efficiency of $81.5 \%$.

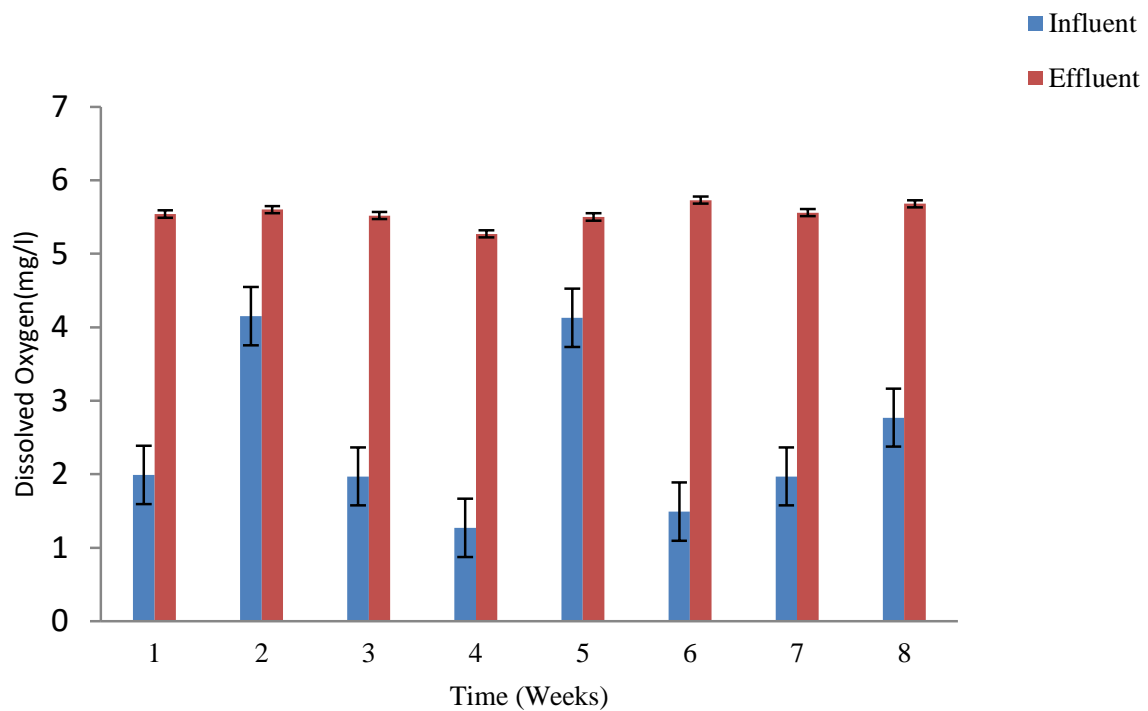

Figure 6: Variations in Dissolved Oxygen (mg/l) of Influent and Effluent (values shown are Mean \pm SE)

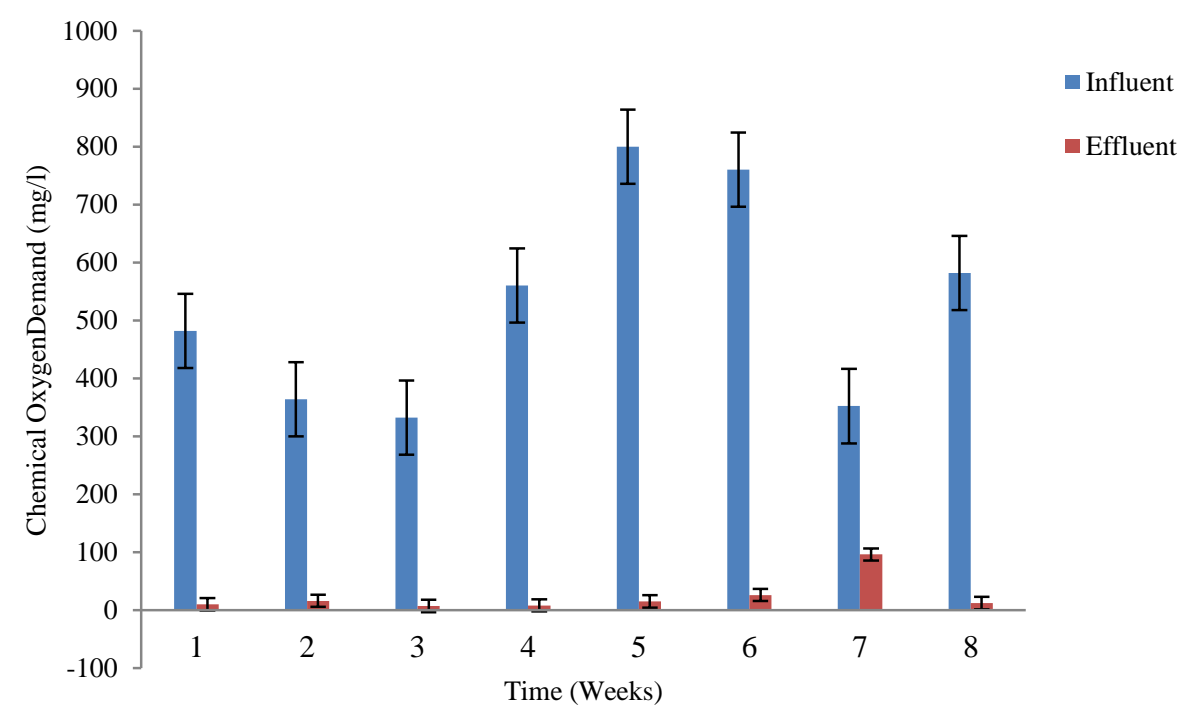

Figure 7: Variations in Chemical Oxygen Demand (mg/l) of Influent and Effluent (values shown are Mean \pm SE)

\subsection{Biological Oxygen Demand (COD)}

Figure 8 indicated that the BOD of both the influent and effluent increased as the experiment progressed. The BOD of the influent was significantly different from that of the effluent $(\mathrm{P}<0.05)$. This was probably because the effluent contained small quantity of organic load, thus lesser concentration of dissolved oxygen would be needed for the decomposition of organic matter. The effluent range of $2-3 \mathrm{mg} / \mathrm{l}$ is within the World Health Organization (WHO) limit for effluent BOD $(30 \mathrm{mg} / \mathrm{l})$ (Table 1). The overall removal efficiency of the UV unit for BOD was $98.2-99.6 \%$ and 
mean removal efficiency $98.9 \%$. This is similar to the result obtained by Devi et al. (2008) who found that the reduction of BOD of wastewater from a coffee processing plant using activated sludge process was $98 \%$.

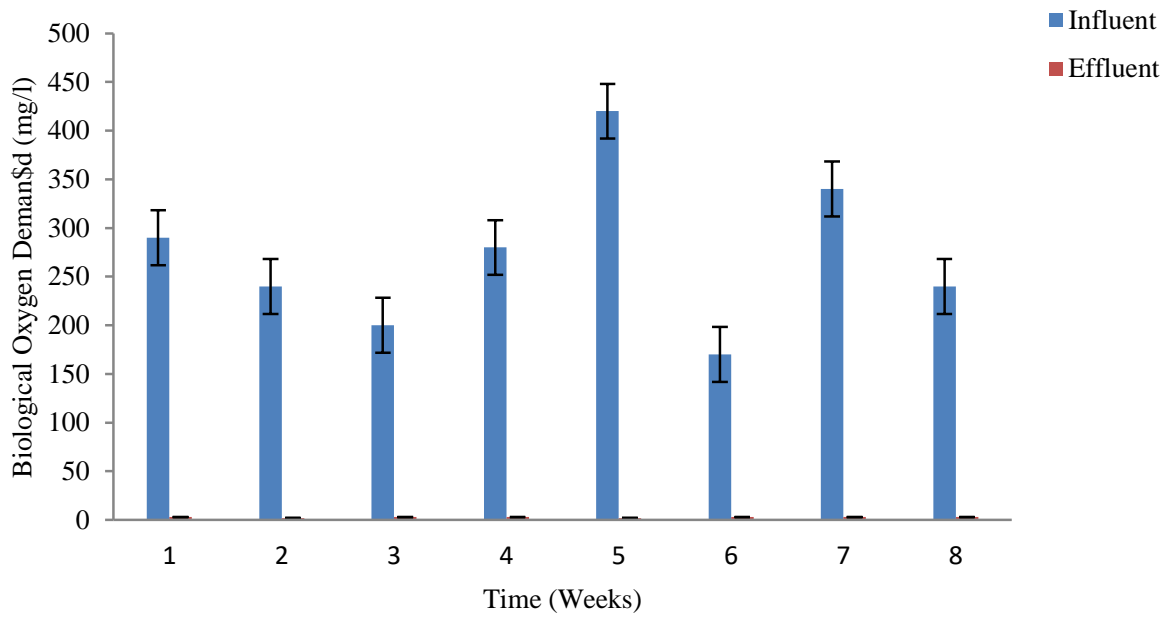

Figure 8: Variations in Biological Oxygen Demand (mg/l) of Influent and Effluent (values shown are Mean \pm SE)

\subsection{Bacteriological Analysis}

\subsubsection{Total Coliform Count (TCC)}

Figure 9 showed the variations of TCC between the inlet, effluent before and after UV. There was a large variation between the inlet, effluent before UV and effluent after UV. The TCC of inlet was indirectly proportional to those of effluent before UV and effluent after UV. The highest level of contamination of wastewater with coliform occurred at the inlet $(3220-3610 \mathrm{cfu} / \mathrm{ml})$. Minor treatment was observed in the effluent before the Ultra Violet radiation ranging from 2040 $2450 \mathrm{cfu} / \mathrm{ml}$, while the major treatment occurred in the effluent after the Ultra Violet radiation with the lowest coliform count of $1-13 \mathrm{cfu} / \mathrm{ml}$, this conform with Federal Ministry of Environment limit (400MPN/100ml) (Table 1). The treatment drastically reduced coliform but does guarantee its complete elimination. Overall removal efficiency for coliform ranged from 99.3 - 99.9\% with mean removal efficiency of $99.6 \%$.

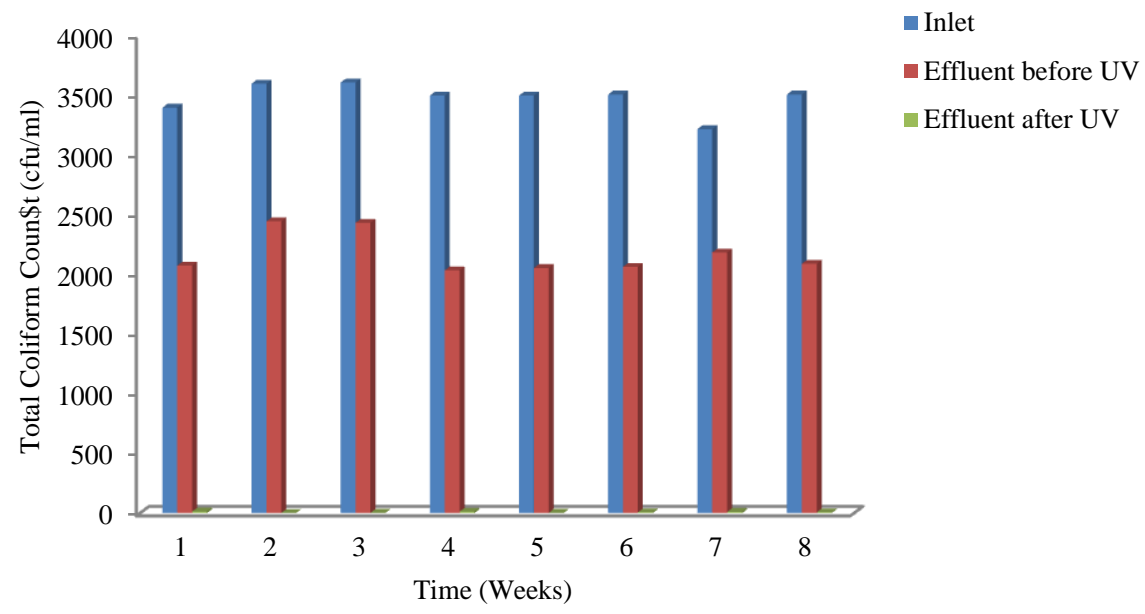

Figure 9: Variations in TCC (cfu/ml) of Influent, Effluent before and after UV

\subsubsection{Total Bacteriological Count (TBC)}

Figure 10 showed the variations in TBC between the inlet, effluent before and after UV. There was a large variation between the inlet, effluent before UV and effluent after UV. The TBC of inlet was 
inversely proportional to that of effluent before and after UV. Contamination was highest at the inlet with Bacteria Count (BC) of $5540-5940 \mathrm{cfu} / \mathrm{ml}$. Minor treatment took place at the effluent before UV ray with Bacteria Count ranging from $96-3430 \mathrm{cfu} / \mathrm{ml}$ while major treatment took place at the effluent after UV ray unit with $\mathrm{BC}$ of $1-54 \mathrm{cfu} / \mathrm{ml}$. This conformed to the Federal Environmental Protection Agency limit for TBC (100MPN/ml) (Table 1). Overall efficiency ranged from $43.7-99.9 \%$ while the mean efficiency removal was $89.9 \%$.

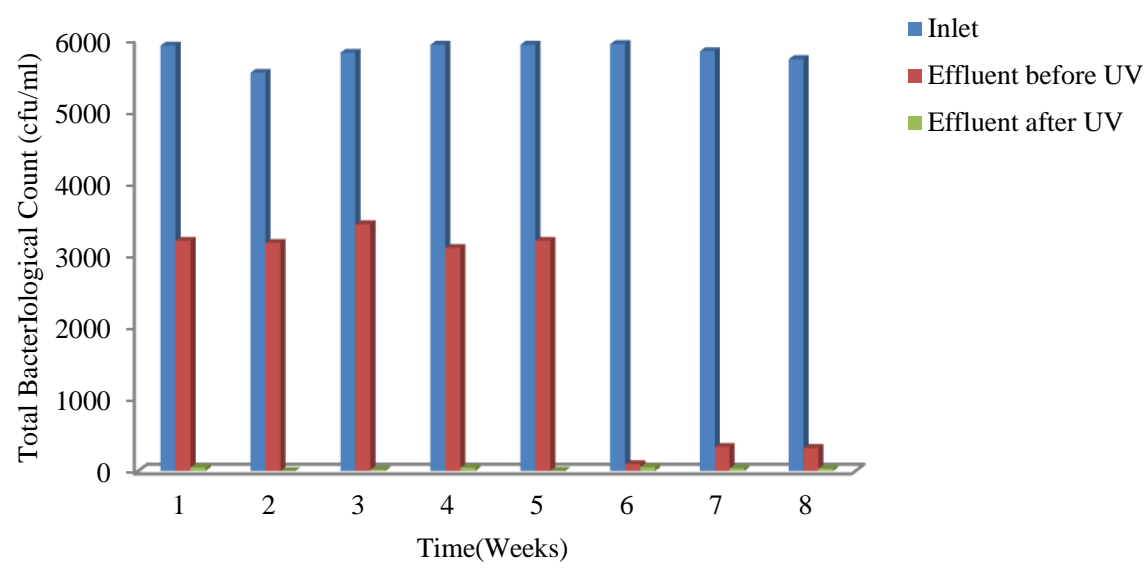

Figure 10: Variations in TBC (cfu/ml) of Influent, Effluent before and after UV

\subsubsection{Faecal Count (FC)}

Figure 11 showed variations in FC between the inlet, effluent before and after UV. The inlet was consistent throughout the period of study with high values (> 1600). The FC of inlet was inversely proportional to those of effluent before UV and effluent after UV. Inlet's FC was consistently high ( $>$ 1600) throughout the study period. The lowest faecal content in the wastewater was observed after the UV ray unit, where there was little (22) or no faecal count (0) compared to the effluent before UV ray unit $(120-1600 \mathrm{cfu} / \mathrm{ml})$. The occurrence of zero faecal count in the second and fifth week conformed to the World Health Organization's (WHO, 2009) standard for faecal coliform in domestic water; zero faecal count per $100 \mathrm{ml}$. The effluent after UV ray unit also agreed with the Standard Guidelines for Effluent discharge in Nigeria (400MPN/100ml). The overall removal efficiency of Ultra violet unit for faecal count was $97.9-100 \%$, with a mean efficiency of $98.9 \%$.

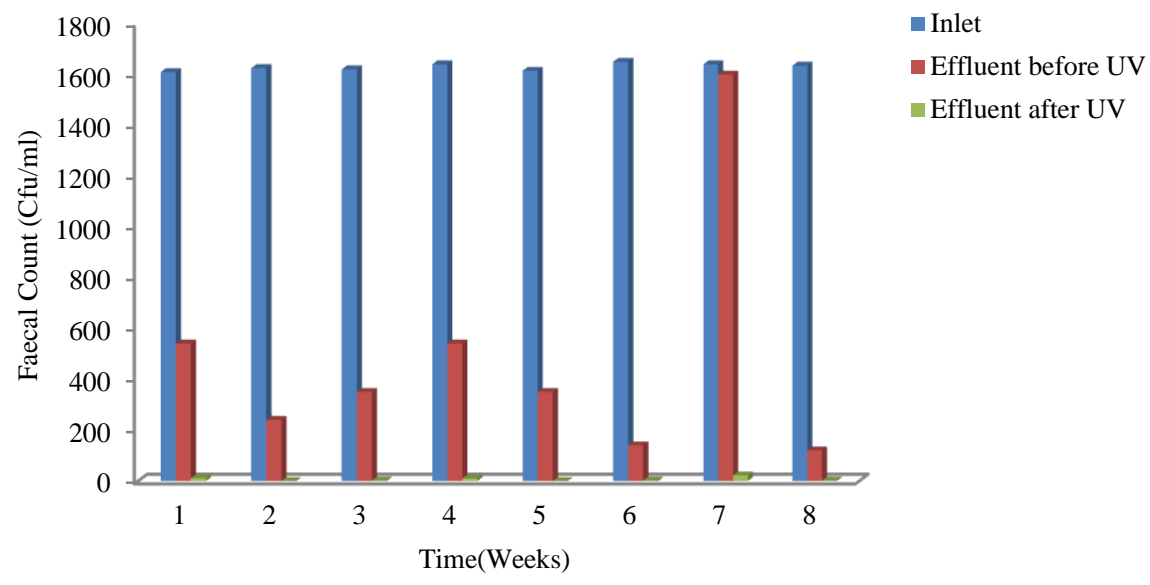

Figure 11: Variations in FC (cfu/ml) of Influent, Effluent before and after UV

\subsection{Statistical analysis}

Table 2 indicated that there were positive correlations between Conductivity and DO $(r=0.172)$, Conductivity and TSS $(r=0.208)$, Temperature and $\mathrm{pH}(\mathrm{r}=0.613)$, $\mathrm{pH}$ and TDS $(\mathrm{r}=0.644)$, DO and TSS $(r=0.364)$, COD and TDS $(r=0.096)$. However, Temperature showed negative correlations with Conductivity $(r=-0.723)$, DO $(r=-0.441)$, COD $(r=-0.521)$, TSS $(r=-0.502)$ and TDS $(r=-0.438)$. 
Negative correlations were also observed between Conductivity and COD $(r=-0.100)$, DO and TDS $(\mathrm{r}=-0.210)$, DO and COD $(r=-0.214)$, COD and TSS $(r=-0.001)$.

Table 2: Two-Tailed Pearson's Correlation Coefficient values among the studied physicochemical parameters.

\begin{tabular}{|c|c|c|c|c|c|c|c|}
\hline Parameters & Temperature & $\mathrm{pH}$ & Conductivity & DO & COD & TSS & TDS \\
\hline Temperature & 1 & & & & & & \\
\hline $\mathrm{pH}$ & 0.613 & 1 & & & & & \\
\hline Conductivity & -0.723 & -1.588 & 1 & & & & \\
\hline $\mathrm{DO}$ & -0.441 & -0.675 & 0.172 & 1 & & & \\
\hline COD & -0.521 & -0.246 & -0.100 & -0.214 & 1 & & \\
\hline TSS & -0.502 & -0.002 & 0.208 & 0.364 & -0.001 & 1 & \\
\hline TDS & -0.438 & 0.644 & 0.009 & -0.210 & 0.096 & & 1 \\
\hline
\end{tabular}

\subsection{Conclusion}

Physicochemical parameters' values except TSS and TDS were within the permissible limits of World Health Organisation (WHO), Federal Environmental Protection Agency (FEPA) and the National Guidelines of Federal Ministry of Environment (FMEnv). Bacteriological analysis (TCC, TBC, FC) results were all within the permissible limit of WHO and FEPA with high mean removal efficiency of 99.6\% for TCC, $89.9 \%$ for TBC and $98.9 \%$ for FC. This treatment plant was thus quite effective in biological treatment of wastewater. However, there is an urgent need for appropriate steps to be taken for proper management and sanitation of the wastewater before discharging it to the stream, in order to ensure to total conformity with the approved standards.

Based on the findings of the investigation, the following recommendations were made:

i. Algal removal facilities should be introduced to improve the removal efficiency of Total Dissolved Solids and Total Suspended Solids.

ii. Efforts should be geared towards full utilization of the plant capacity so as to maximize its full potentials.

iii. There must be continuous monitoring of the efficiency of the wastewater treatment plant so as to enhance biological treatment of wastewater and ensure sustained adherence to permissible standards.

iv. In line the success of the Wupa Wastewater Treatment Plant in remediating polluted water mostly from municipal activities, similar facilities should be provided at all State Capitals in Nigeria with a view to reduce the negative impacts of untreated wastewater in the environments

\section{References}

Aguilar-López, R., López-Pérez, P.A., Penã-Caballero, V. and Maya-Yescas, R. (2013). Regulation of an activate sludge wastewater plant via robust active control design. Int. J. Environ Res, 7, 61-68

American Public Health Association (APHA) (2005). Standard Methods for the Examination of Water and Wastewater, (21st Ed). Washington, D. C., Pp. 1368.

Benethan, I. A. (2003). Microbiology with Health care Application. Star Publishing Company, USA, Pp. 111-125.

Chessbrough, M., (2004). Medical Laboratory Manual for Tropical Countries, (4th Ed). Cambridge University Press, Cape Town, Pp. 143-157.

Devi, R. and Dahiya, R.P. (2008). COD\&BOD removal for domestic wastewater generated in decentralized sectors. Bioresour Technology, 99, 344-349.

Federal Ministry of Environmental (FMEnv). (2013). National Environmental Protection Regulations (Effluent Limitation) Regulations. Federal Republic of Nigeria Official Gazette, Lagos, Pp. 42-78 
Federal Environmental Protection Agency (FEPA). (2005). National Environmental Protection Regulations (Effluent Limitation) Regulations. Federal Republic of Nigeria, Official Gazette, Lagos, Pp. 42-78.

Healy, M.G., Rodgers, M. and Mulqueen, J. (2006). Performance of stratified sand filter in removal of chemical oxygen demand, total suspended solids from high strength wastewater. Journal of Environmental Management, 83, 409-415

Hunter, P. R. and Syed, Q. (2001). Community Surveys of Self-reported diarrhea, can dramatically overestimates in size of outbreaks of Waterborne Cryptosporidioses. Water Science Technology, 43, 27-30.

Ikupolati, A.O. (2005). Sewage Disposal. Microsoft Corporation. Encarta Encyclopedia Lenore, S., Clesceri, A. D. and Eugene, W. (2005). Standard Methods for Examination of Water \& Wastewater Method 5210B. Washington, DC: American Public Health Association, American Water Works Association, and the Water Environment Association.

Nielsen, P. H., Thomsen, I. R. and Nielsen, J. L. (2004). Bacteria Composition of Activated SludgeImportance for Floc and Sludge Properties. Water Science and Technology, 49, 31-58

Saminu, A., Chukwujama, I.A., Garba, A. and Nnamdi, M.M.(2017). Performance evaluation of Wupa wastewater treatment plant, Abuja. American Journal of Engineering Research (AJER), 87-88.

Slater, N. (2006. Sequencing batch reactors: cost effective wastewater treatment. In: Alberta Water and Wastewater Operators Association, $32^{\text {nd }}$ Annual Operators Seminar, 16 March 2006, Banff, Alberta

Sotomayor, O.A.Z, Park, S.W, Garcia, C. (2001). A simulation benchmark to evaluate the performance of advanced control techniques in biological wastewater treatment plants. Braz J

Chem. Eng, 18, 81-10113.

Uzoigwe, C. I. and Agwa, O. K. (2012). Microbiological quality of water collected from boreholes sited near refuse dumpsites in Port Harcourt, Nigeria. African Journal of Biotechnology, 11(3), 31353139 .

Willey, J. M., Sherwood, L.M. and Woolverton, C.J. (2008), Prescott Harley and Kleins Microbiology. (7th Ed). Mc-Graw Hill, New York, Pp. 1049-1088.

World Health Organization (WHO) (2009). Global Water Supply and Sanitation Assessment. WHO Press, Switzerland, 1, 4-10 